\title{
Transparency in Midyat Traditional Syriac Houses
}

\author{
Mehmet Akif Kuyumcu ${ }^{1}$ \\ ORCID: 0000-0002-7170-7324
}

\author{
F. Demet Aykal 2 \\ ORCID: 0000-0003-2424-0407
}

\begin{abstract}
*
The concept of transparency is a very important design criterion for the user to perceive the architectural structures and to interpret these structures, thanks to the literal and connotations that the user evokes. In the scope of the article, the concept of transparency in architecture is defined and its relation with architecture and different interpretations in architecture are analyzed. Midyat Traditional Syriac Houses; data obtained from literature reviews, on-site observation and questionnaires with different user maggots were evaluated. Data were obtained with The Shapiro-Wilk Test. Privacy phenomenon and transparency interpretations in architecture shaped within the framework of this phenomenon have been examined in Midyat Syriac Traditional Housing architecture. The reflections of privacy criteria that emerged depending on lifestyles to the architectural structure in terms of transparency have been determined. In the study, it's understood that the concept of life style and privacy of societies affects the formation of the house in which they live, both in the internal space regulation and in the connection with the outside world, in other words with the ratio of transparency on the fronts. The fact that the subject hasn't been done before in the literature indicates the contribution of the study to science.
\end{abstract}

Keywords: Midyat, syriac houses, traditional house, transparency in architecture.

\footnotetext{
1 PhD Student, Dicle University Faculty of Architecture Department of Architecture. E-mail: akifab@hotmail.com.

2 Prof. Dr. Dicle University Faculty of Architecture Department of Architecture.

E-mail: demetaykal@gmail.com.

* This study was produced from the master thesis dated June 2019, titled An Investigation of the Concept of Transparency in terms of Privacy in the Housing Architecture of Different Ethnic Groups: The Example of Traditional Midyat Houses.
} 


\section{Midyat Geleneksel Süryani Evlerinde Şeffaflık}

\author{
Mehmet Akif Kuyumcu ${ }^{3}$ \\ ORCID: 0000-0002-7170-7324
}

\author{
F. Demet Aykal 4 \\ ORCID: 0000-0003-2424-0407
}

Öz

Her toplumun farklı yaşam tarzı, farklı dini inancı ve farklı kültürel öğeleri vardır. Bu farklılıklar toplumun mahremiyet olgusunu oluşturmaktadır. Toplumlara göre değişkenlik gösteren bu mahremiyet olgusu mimari yapılaşmada şeffaflık kavramının da değişkenlik göstermesine neden olmuştur. Bu değişkenliklerin elverdiğ ï ölçüde mimarinin biçimlenmesini etkileyen şeffaflık kavramı, kullanıcıda çağrıştırdı̆̆ı düz anlam ve yan anlamlar sayesinde mimari yapıların kullanıcı tarafindan algılanması ve bu yapıların yorumlanmasında çok önemli bir tasarım kriteridir. Makale kapsamında mimaride şeffaflık kavramı tanımlanarak, bu kavramin mimariyle olan ilişkisi ve mimarideki farklı yorumlar incelenmiştir. Midyat Geleneksel Süryani Evleri; literatür taramaları, yerinde gözlem ve farklı kullanıcı profilleri ile yapılan anketler sonucunda elde edilen veriler doğrultusunda değerlendirilmiştir. Veriler, The Shapiro-Wilk Testi ile elde edilmiştir. Mahremiyet olgusu ve bu olgu çerçevesinde şekillenen mimaride şeffaflık yorumları Midyat Süryani Geleneksel Konut mimarisinde incelenmiştir. Yaşam tarzlarına bağlı olarak oluşan bu mahremiyet ölçütlerinin şeffaflık açısından mimari yapıya yansımaları tespit edilmiştir. Çalışmada toplumların yaşam tarzı ve mahremiyet olgusunun; içinde yaşadıkları konutun biçimlenmesini, hem iç mekan düzenlemesinde hem de dış dünyayla olan bağlantıda yani cephelerdeki şeffaflık oranıyla etkilediği anlaşılmıştır. Konunun literatürde daha önce yapılmamış olması, çalışmanın bilime katkısını ifade etmektedir.

Anahtar Kelimeler: Midyat, süryani evleri, geleneksel konut, mimaride şeffaflı.

\footnotetext{
${ }^{3}$ Doktora Öğrencisi, Dicle Üniversitesi Mimarlık Fakültesi Mimarlık Bölümü.

E-mail: akifab@hotmail.com

${ }^{4}$ Prof. Dr. Dicle Üniversitesi Mimarlık Fakültesi Mimarlık Bölümü.

E-mail: demetaykal@gmail.com
}

idealkent @ Kent Araştırmaları Dergisi (Journal of Urban Studies)

http://idealkentdergisi.com

Geliş Tarihi Received Date: 08.03.2021 Kabul Tarihi Accepted Date: 13.12.2021 


\section{Introduction}

The need of establishing relationships and communication among the people as a result of communal living and social life has arisen. In accordance with this need, people form the environment and spaces they live in and define them. When people form these spaces, they can not ignore their beliefs, lifestyles and cultures. Because the architectural forming of the houses they will lead a life in should respond to the privacy phenomenon they have. Accordingly, the transparency in a house has changed in parallel with the privacy conception of the people who will live in that house.

The concepts of transparency and privacy examined in the article have a prominent place in the field of architecture as well as in the social field. The residence, in terms of providing user comfort in shaping the architectural structure, should be designed according to the lifestyles and beliefs of the people they will live in it. Each society has a different lifestyle, different religious beliefs and cultural elements. Due to these differences, each society's privacy phenomenon is different from each other. This privacy phenomenon differing from society to society has caused the concept of transparency to vary in architectural construction too. That's why transparency conception in the architectural structures of societies with different cultures has been different. There are lots of studies on cities, societies and cultures.

Zorlu and Keskin (2017), in their studies investigating the Concept of Privacy in Culture-House Interaction, concluded that the phenomenon of privacy has an important place in the shaping the traditional Turkish house and that the teachings of the Islamic religious belief lie at the basis of the phenomenon of privacy in Turkish culture.

Şengül (2017), was examined the Muslim, Christian and Jewish houses in the city center of Mardin at the end of the 19th century, concluded that the relevant spaces have traditional features.

Karagülle (2009), compared the traditional houses built in Mardin on the basis of local data and the new houses built recently.

Çelik (2010), in the article of "Cities: The Transformation of Anatolia, the Future of Turkey", pointed out that the factors that differentiate cities from each other, such as the demographic structure of cities and their demographic transformation, their educational indicators, historical, cultural and geographical qualities, should be mentioned. 
Uçar and Rifaioğlu (2011), in the article of "Spatial Presentation of Local Identity and Its Conservation in Québec City" were mentioned the importance of the way people live and the way they use the place, and the protection of the meanings and values they attribute to the ground is a contemporary approach in preserving the historical city. In this case, it becomes important not only to understand the visible and material qualities of the city, but also to understand the abstract dynamics connected to the material, and to analyze the spiritual meaning and usage styles that the inhabitants of the city attribute to the city and to relate it with the material.

Erman (2010), in the article of "Revolutionary" Neighborhood in the City Periphery: The Changing Meaning of the Neighborhood from 1970s to 2000s and Conflicts and Conflicts on the Neighborhood" mentioned that "Neighborhood is also a fiction of belonging. The relationship between place and belonging has been the subject of many studies. The place of residence can be as effective as class, origin, ethnicity and gender in the formation of a person's identity. (Keith and Pile, 1993). This situation is explained by the concept of space / place and identity (Proshansky, Fabian, and Kaminoff, 1983; Rivlin, 1987; Altman and Low, 1992; Williams, Patterson, Roggenbuck, and Watson, 1992; Lovell, 1998). In addition to the fact that the place / neighborhood affects the identity of the people living there, it is also the case that the common characteristics of the people living there affect the identity of the place: the clustering of a certain group, especially an ethnic or minority group, in a space can create an identity that is specific to that place (Erdentug and Colombijn, 2002).

All these studies were mentioned the importance of studies on cities, societies and cultures.

Due to the changing world conditions from past to present, society structure and lifestyle have also changed. These concepts, developing and changing in parallel with this change in societies, have started to become a crucial design criterion in shaping the architectural structure. Privacy phenomenon and transparency interpretations in architecture shaped within the framework of this phenomenon have been examined in Midyat Syriac Traditional Housing architecture.

In the study, it was tried to determine whether the Traditional Midyat Syriac Houses in the district of Mardin were designed in terms of transparency in accordance with the privacy cultures of the users. As a result of the observations, it has been observed that the phenomenon of privacy is variable ac- 
cording to cultures, but these variations are not reflected in residential buildings. The main problem of the study is to determine whether there is a relationship between transparency and privacy. While designing houses belonging to Syriac, the question whether the privacy perceptions of the groups affect the transparency of the residence and whether the users are satisfied with the housing they live in according to the privacy criteria was set out.

The aim of the study is to examine the privacy phenomenon of the variations in the residential buildings of the Syriac residents in Midyat.

In the method of the study questionnaire and interview techniques were used. A questionnaire with 15 questions were prepared with the rules of 5point Likert method. It was applied to 40 Syriac residence users, one female and one male in each house. The questionnaire questions were grouped to measure the approaches of the users under the concepts of visual transparency, perceptual transparency, cultural transparency and psychological transparency. It was questioned whether these people were satisfied with the dwelling they lived in in terms of user comfort and satisfaction. Survey results were evaluated in percentages using SPSS for Windows version 24.0 package program for statistical analysis. The conformity of the scores of the answers given to the questionnaire to the normal distribution was tested with the Shaphiro Wilk Test.

As a result of the determinations it has been observed that the socio-cultural structure, religious beliefs and lifestyles of societies shape the privacy phenomenon of that society, and these conceptions of privacy are effective in shaping the architectural structure in terms of transparency.

\section{Transparency Concept In Architecture}

The concept of transparency has had different definitions during the historical process. Going through changes in time, these definitions have caused the concept of transparency to be examined more deeply. As the definition, transparency is defined as "the quality or state of being transparent"; transparency, transmittance of light or, picture, printed text or mark made visible by light shining through from behind on special, translucent substance" in 1591. However, in 1615, transparency is expressed as "the thing that is transparent" as concept; in 1807, "photograph or picture designed for being able to be viewed through the light it transmits on glass or other transparent material" (Aytıs \& Göker, 2010, s. 88). 
Besides its general use of the concept of transparency, the fact that it has been used frequently in the field of architecture has given chance to this concept to be explained in terms of architecture as well. Starting from this, the concept of transparency analyzed in architecture, just as stated above, has been defined and interpreted differently. With these interpretations, the concept of transparency in architecture has taken a physical organizational and symbolic identity (İleriye, 2007, s. 41).

Within the scope of the article, the different interpretations of transparency used in Architecture have been evaluated as visual, structural, perceptual, cultural and psychological transparency.

\section{Transparency as a Visual Element}

With the 20th century, there have been changes in the concept of transparency as well. The fact that the starting to use the concept of transparency as a visual element in today's architecture with architectural expression has been associated especially with the use of glass material. In the 20th century in architectural discourse, glass has sometimes been associated with a visual meaning of transparency and sometimes stated with the integrity of form and material. The unity of glass material, having an effect enhancing the visual feature, with the light has shown up with thriving examples that can set an example in today's architectural conception (Asımgil, 2006, s. 72-73).

"Disintegration of the mass" being the most basic feature of transparent architecture and meaning the separation and independence of building components, has been made possible especially with the introduction of technological materials. Enclosure in architecture disappearing with the disintegration of the mass, the absorption of daylight from the glass and numerous walls, glass has been reinterpreted as a building material in architecture. Glass and architecture have become integrated definitely. It can be said that this situation has created a basis for the re-perception of the transparency concept in different dimensions with the reinterpretation of "interior and exterior" in architecture. (Asımgil, 2006, s. 73).

This situation is frequently met in works designed by Frank Lloyd Wright as well. Wright's "tendency to use the glass materialistically" has brought the simplification of the geometry of the glass in the architectural field and the creation of transparency has been enabled by simplifying the geometric use of glass. Starting from the harmony of glass and light, the fact that architectural space moves in harmony makes the transmission of light from outside to inside and from there to other fields easier. 


\section{Transparency in Structural Dimension}

After World War II, the renaissance movement has gained momentum. In parallel with this development, the concepts of transparency and transmittance used to create only botanical gardens such as conservatory and greenhouse in previous years has stood out in pavilions, towers and later in Gothic church structures in Europe after the World War II. In the following years, it has been seen that transparency was used more frequently in public places such as libraries, stations and airports.

When the concept of transparency is considered in a structural meaning, the most important result that can be concluded is that in parallel with the development of technology, the use of transparency in buildings increases. The quality increase in the transparent material used both expands the area of use in building and it becomes more preferred.

\section{Perceptual Transparency}

The sensory information we receive regarding the abstract and concrete objects taking place in the outer world can be defined as perceiving. The first state in the perception process is selectivity. The variables influencing the perceptual selection are related to the features of stimulus and sensor. Stimulus' size, intensity, mobility; and sensor's interest and need have become crucial in selectivity (Illeriye, 2007, s. 24).

In the perception of transparency, distance has also an important place. The factor making the perception of the other object behind the transparent one as not being singular and makes us feel that there is a transparent object in front of the object behind is distance. Perception as the distance can be defined as a kind of three-dimensional vision. Objects evoking the distance and depth senses in patterns are elements becoming clear as perspective, shadow and motion (İleriye, 2007, s. 38).

All these phenomena characterized as perception in transparency have paved the way for architectural structures to be defined as "beautiful" by the people relatively. Ensuring that the transparency in architectural structures is perceived through the senses contributes to forming authentic structures with depth.

\section{Transparency in the Cultural Sense}


Culture means all the set of material and sentimental values created in the process of historical and social development, and the instruments used to create these and convey them to the next generations, and demonstrating the measure of human supremacy to its natural and social environment (TDK, 2019). The word of sect or group is understood to reflect the culture more. This is because people from a specific sect or group believe and worship certain things. In this context, it is stated that culture is identified with the sect. Little differences occurring due to cultural relations among the close societies are evidently separated in societies distant from each other and this separation is felt dramatically.

Occurring in the architectural structures and differing from one society to another, with the culture's effect, this situation can be evaluated as "cultural transparency". Being used in architecture and differing between cultures, this concept is also a guide about culture characters.

The basic perception found in architectural structures formed based on physical conditions and cultural impacts integrates with the privacy conception and the transparency levels of structures have been created within the framework of these lines. With the creation of architectural structures with cultural conceptions, especially the transparency concept has been minimized and the transparent parts can be enclosed in a way close to the opacity. When this situation is evaluated within the framework of culture, privacy and transparency; it can be said that especially the transparency of the culture is the determinant factor on the privacy phenomenon.

\section{Psychological Transparency}

Apart from being a physical character, psychological transparency is defined as a concept covering moral, vital and mental dimensions in its body. Being an indicator of transparency, simplicity can contribute to the people's life quality by creating a perception dimension that is far from selfishness, flamboyancy and earthliness. Actualizing the transparency, evoking the sense of simplicity in individuals as a psychological effect, in architectural spaces can create an effect taking people away from the complexity of life and directing them to the purge from excessiveness and gives them inner peace.

The transparency phenomenon, the basis of the structures created with the purgation and liberation themes in architecture, can create a sense of purification in people and bring relaxation in psychological sense. Encountering 
this phenomenon frequently in architectural structures designed for especially helping people to get rid of the intense pace they experience today and its effects is possible.

\section{Method}

Traditional houses belonging to Syriacs in Isiklar and Akçayaka districts, which are the protected areas in Midyat central districts, have been examined in terms of privacy and transparency. Midyat Traditional Syriac Houses have been evaluated in accordance with the data obtained as a result of photography and surveys carried out with different user profiles.

As a result of the analyzes, observations carried out and surveys applied to the users, the privacy phenomenon of Syriacs living in Midyat and their transparency conception shaped as a result of this phenomenon have been determined. The transparency of Midyat Traditional Syriac Houses shaped by the privacy phenomenon; has been examined in terms of transparency on the facade (openness - enclosure) and transparency in the arrangement of interior space. In which levels of visual, structural, perceptual, cultural and psychological transparency are influenced by Syriac's privacy concept on the houses they live in, in terms of transparency have been investigated.

20 Syriac houses have been examined in order to determine how these transparency dimensions reflect on Midyat Traditional Syriac Houses. A 15question survey prepared using 5-Point liker scale method have been applied to 20 residents. The survey questions have been classified in order to evaluate the approaches of the users under the concepts of visual, perceptual, cultural and psychological transparency. 7th, 10th and 14th questions have been prepared to question the concepts of visual transparency; 9th and 13th are for perceptual transparency; 1st, 2nd, 4th, 6th, 8th and 15th are for cultural transparency; 3rd, 5th, 11th and 12th are for psychological transparency. The survey has been carried out with a total of 40 people, each residence and privacy criteria, lifestyles and transparency conceptions of these people have been questioned. Whether these people are satisfied with the resident they live in or not in terms of user comfort and content have been questioned.

A total of 20 traditional houses whose locations are marked in Midyat map, including 15 houses in Akçayaka District, and 5 houses in Işıklar District have been examined in the field study conducted about Syriacs (Figure 1). 
As a result of the study carried out; it has been identified that the transparency concept has architectural reflections in Midyat Traditional Syriac Houses. The findings have been obtained by evaluating the questions asked to the users with the Shapiro-Wilk Test and the chart below has been created. The users have been asked to choose one of the answers of not at all, a little, rather, much, very much to the questions asked within the scope of the test. Answers have been gathered from a total of 40 users (Table 1).

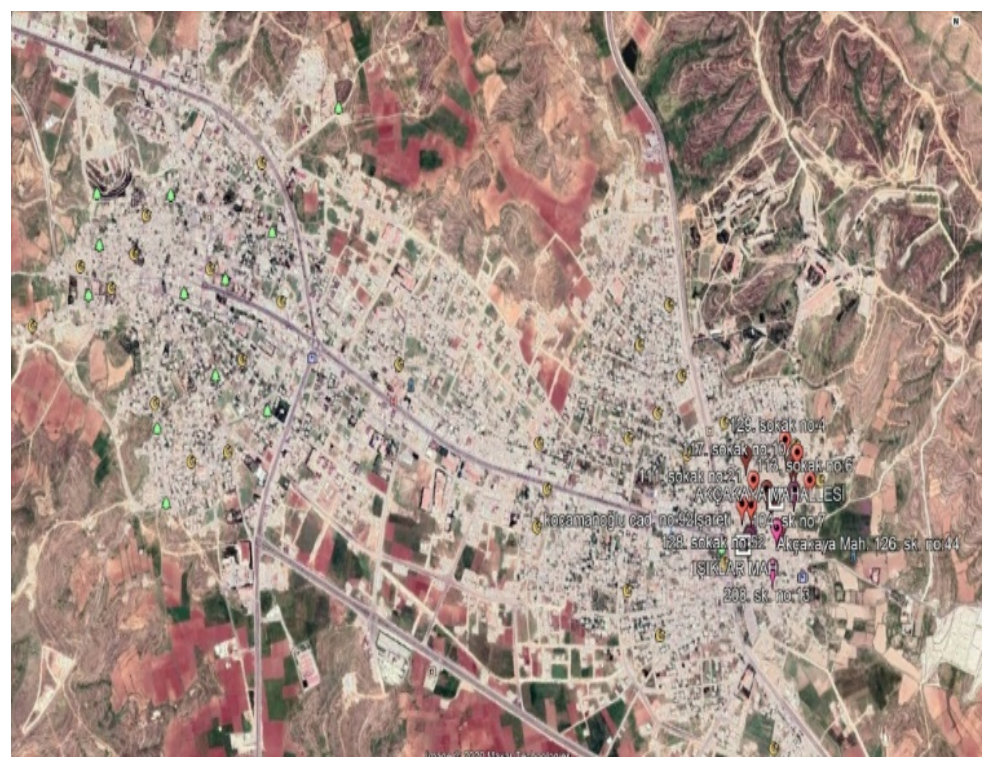




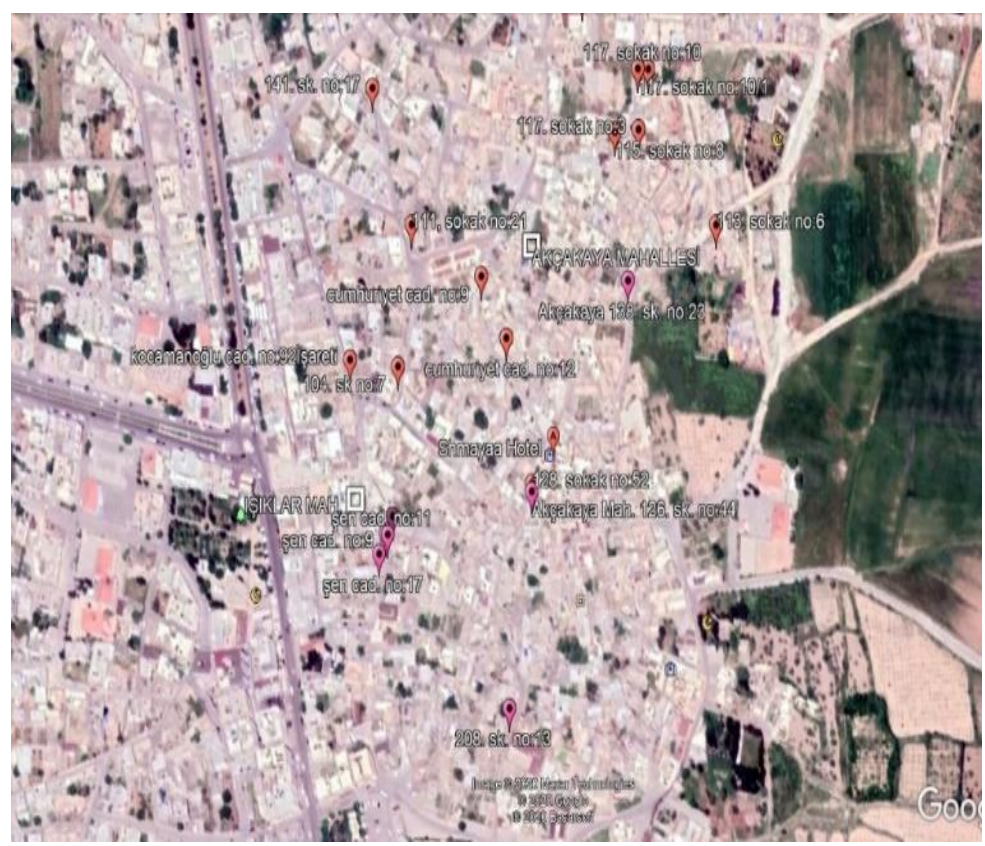

Figure 1. Map of Midyat and Syriac Houses Examined (Reference: Google Earth, 2020)

Table 1. The Shapiro-Wilk Test (Distribution control test for the answers of survey questions)

\begin{tabular}{|c|c|c|c|c|}
\hline \multirow{2}{*}{\multicolumn{2}{|c|}{ Questions }} & & \multicolumn{2}{|l|}{ Syriac } \\
\hline & & & \multirow{2}{*}{$\begin{array}{c}\text { Number } \\
1\end{array}$} & \multirow{2}{*}{$\frac{\%}{2.5 \%}$} \\
\hline 1. & Does the house you live in play a role in com- & Not at all & & \\
\hline & $\begin{array}{l}\text { plying with your family structure and the } \\
\text { number of family members instead of living }\end{array}$ & A little & 1 & $2.5 \%$ \\
\hline & in a condo? & Rather & 2 & $5.0 \%$ \\
\hline & & Much & 0 & $0.0 \%$ \\
\hline & & Very Much & 36 & $90.0 \%$ \\
\hline \multirow[t]{4}{*}{2.} & In terms of your lifestyle and privacy, are you & Not at all & 3 & $7.5 \%$ \\
\hline & kitchen, yard in your home? & A little & 1 & $2.5 \%$ \\
\hline & & Rather & 3 & $7.5 \%$ \\
\hline & & Much & 14 & $35.0 \%$ \\
\hline
\end{tabular}




\begin{tabular}{|c|c|c|c|c|}
\hline & & Very Much & 19 & $47.5 \%$ \\
\hline \multirow[t]{5}{*}{3.} & \multirow[t]{5}{*}{ Is your home private enough? } & Not at all & 2 & $5.0 \%$ \\
\hline & & A little & 0 & $0.0 \%$ \\
\hline & & Rather & 0 & $0.0 \%$ \\
\hline & & Much & 7 & $17.5 \%$ \\
\hline & & Very Much & 31 & $77.5 \%$ \\
\hline \multirow[t]{5}{*}{4.} & \multirow{5}{*}{$\begin{array}{l}\text { How important is it to have separate rooms } \\
\text { for women and men in the house for you? }\end{array}$} & Not at all & 31 & $77.5 \%$ \\
\hline & & A little & 3 & $7.5 \%$ \\
\hline & & Rather & 2 & $5.0 \%$ \\
\hline & & Much & 0 & $0.0 \%$ \\
\hline & & Very Much & 4 & $10.0 \%$ \\
\hline \multirow[t]{5}{*}{5.} & \multirow{5}{*}{$\begin{array}{l}\text { Is there a difference between the day and } \\
\text { night part in terms of planning in your home? } \\
\text { Is it important for you to protect the family } \\
\text { members' privacy of the night part when } \\
\text { welcoming the unfamiliar guests to your } \\
\text { home at the entrance? }\end{array}$} & Not at all & 24 & $60.0 \%$ \\
\hline & & A little & 3 & $7.5 \%$ \\
\hline & & Rather & 8 & $20.0 \%$ \\
\hline & & Much & 3 & $7.5 \%$ \\
\hline & & Very Much & 2 & $5.0 \%$ \\
\hline \multirow[t]{6}{*}{6.} & \multirow{6}{*}{$\begin{array}{l}\text { Does it bother you that the guests (male-fe- } \\
\text { male) coming to your house use the common } \\
\text { areas (living room-wc-kitchen) with the fam- } \\
\text { ily members? }\end{array}$} & Not at all & 38 & $95.0 \%$ \\
\hline & & A little & 2 & $5.0 \%$ \\
\hline & & Rather & 0 & $0.0 \%$ \\
\hline & & Much & 0 & $0.0 \%$ \\
\hline & & Very Much & 0 & $0.0 \%$ \\
\hline & & Not at all & 3 & $7.5 \%$ \\
\hline
\end{tabular}


7. When you have the guest, are the kitchen and wet areas far enough from the rooms such as the living room and lounge for family members to use comfortably?

\begin{tabular}{lll} 
A little & 1 & $2.5 \%$ \\
\hline Rather & 7 & $17.5 \%$ \\
\hline Much & 14 & $35.0 \%$ \\
\hline Very Much & 15 & $37.5 \%$
\end{tabular}

8. Do you need hosting the guests coming to Not at all $22 \quad 55.0 \%$ your house in a separate room

\begin{tabular}{lcc} 
Not at all & 22 & $55.0 \%$ \\
\hline A little & 6 & $15.0 \%$ \\
\hline Rather & 3 & $7.5 \%$ \\
\hline Much & 4 & $10.0 \%$ \\
Very Much & 5 & $12.5 \%$
\end{tabular}

9. Is the fact that the main entrance door of your Not at all $\quad 1 \quad 2.6 \%$ house opens to the yard instead of directly to the street important for you?

\begin{tabular}{lll} 
Not at all & 1 & $2.6 \%$ \\
\hline A little & 1 & $2.6 \%$ \\
\hline Rather & 3 & $7.7 \%$ \\
\hline Much & 4 & $10.3 \%$ \\
\hline Very Much & 30 & $76.9 \%$
\end{tabular}

10. How important is it for you that the windows, doors, balconies, or yard walls if any, of your house are private visually for people passing by the street?

\begin{tabular}{lll} 
Not at all & 2 & $5.0 \%$ \\
\hline A little & 4 & $10.0 \%$ \\
\hline Rather & 13 & $32.5 \%$ \\
\hline Much & 7 & $17.5 \%$ \\
\hline Very Much & 14 & $35.0 \%$
\end{tabular}

11. Does the fact that your windows open to the

Not at all 7

$17.5 \%$ street bother you psychologically?

\begin{tabular}{lll}
\hline A little & 6 & $15.0 \%$ \\
\hline
\end{tabular}




\begin{tabular}{|c|c|c|c|c|}
\hline & & Rather & 7 & $17.5 \%$ \\
\hline & & Much & 11 & $27.5 \%$ \\
\hline & & Very Much & 9 & $22.5 \%$ \\
\hline \multirow[t]{5}{*}{12.} & \multirow{5}{*}{$\begin{array}{l}\text { Do you need to use shutters or thick curtains } \\
\text { so that the interior cannot be seen from the } \\
\text { windows opening to the street? }\end{array}$} & Not at all & 2 & $5.0 \%$ \\
\hline & & A little & 4 & $10.0 \%$ \\
\hline & & Rather & 6 & $15.0 \%$ \\
\hline & & Much & 10 & $25.0 \%$ \\
\hline & & Very Much & 18 & $45.0 \%$ \\
\hline \multirow[t]{5}{*}{13.} & Does the fact that whether your windows & Not at all & 20 & $50.0 \%$ \\
\hline & your privacy? & A little & 7 & $17.5 \%$ \\
\hline & & Rather & 2 & $5.0 \%$ \\
\hline & & Much & 2 & $5.0 \%$ \\
\hline & & Very Much & 9 & $22.5 \%$ \\
\hline \multirow[t]{5}{*}{14.} & $\begin{array}{l}\text { Does the fact that you are being seen by your } \\
\text { neighbors when using your yard and terraces }\end{array}$ & Not at all & 18 & $45.0 \%$ \\
\hline & bother you? & A little & 7 & $17.5 \%$ \\
\hline & & Rather & 8 & $20.0 \%$ \\
\hline & & Much & 1 & $2.5 \%$ \\
\hline & & Very Much & 6 & $15.0 \%$ \\
\hline \multirow[t]{5}{*}{15.} & Is it important for you to have specific spaces & Not at all & 39 & $97.5 \%$ \\
\hline & & A little & 0 & $0.0 \%$ \\
\hline & & Rather & 0 & $0.0 \%$ \\
\hline & & Much & 0 & $0.0 \%$ \\
\hline & & Very Much & 1 & $2.5 \%$ \\
\hline
\end{tabular}


The study; It was produced from his master's thesis titled "An Investigation of the Concept of Transparency in Housing Architecture of Different Ethnic Groups in Terms of Privacy: The Case of Traditional Midyat Houses". The data, findings and results transferred in the study were taken from the thesis. The study and evaluation have been carried out covering 20 houses. However, in order not to ruin the article format, in the study only 5 houses have been exemplified by the transparency analyzes based on observation and survey. The results have been obtained through the findings of 20 houses.

\section{Findings}

In this part of the study, the reflections of the concept of transparency, which is shaped by the privacy understanding of the users as a result of the data obtained from the questionnaires and observational impressions, on the traditional Syriac Houses in Midyat were conveyed.

\section{Transparency In Syriac Houses}

Not having a secluded and introverted lifestyle, Syriacs do not have a culture of separating the men-women spaces, thus the structure in terms of planning consists of two parts as sitting and sleeping. Wet areas and kitchen are located at the terrace. It has been observed that the guests coming over use the same spaces with the family members and family members are not disturbed by this situation. The structures have yards and they offer an extrovert life. Generally, the life on the yard and terrace can be seen by the neighbors. It has been observed that although the structures are visually transparent, the windows of the upper floor and the terrace facing the yard are covered with iron railings, when the door is knocked; it is not opened unless Syriac is spoken. It is thought that since Syriacs are minority in this region, they need to take such measures in terms of security.

It has been observed that the interaction between the outer world and the structure is rough. Although the structures have a transparent function in terms of planning and lifestyle, the fact that the windows in spaces are located at the upper floor and the wall separating the yard from the street is high and blind, the building has given a perceptually opaque impression when it is viewed from the street due to the wall mentioned.

With the characteristics, plans and images of 5 traditional Syriac houses, visual, structural, perceptual, cultural and psychological transparency analysis 
and survey evaluation based on the observation have been made as follows. Findings are interpreted separately for each house. (Figure 2-Figure 6 and Table 2-Table 6).

\begin{tabular}{lllll}
\hline & Structure Name: & SURYANI 1 & Structure Type: & MASONRY \\
\cline { 2 - 4 } 1 & Structure Order: & ATTACHED & Window protector: & IRON RAILING \\
\cline { 2 - 4 } & Facade Number: & 2 FACADES & Garden Walling: & \\
\hline \multicolumn{4}{c}{ FLOOR PLANS } \\
\hline
\end{tabular}

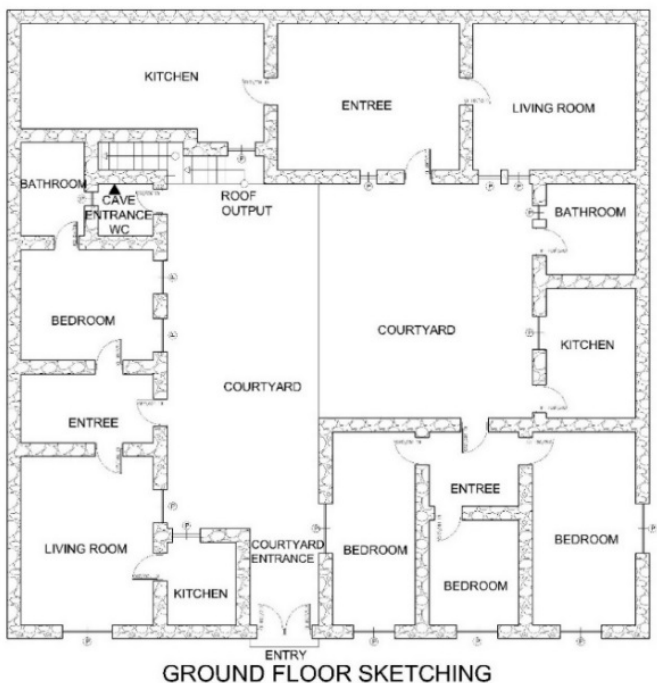

IMAGES 

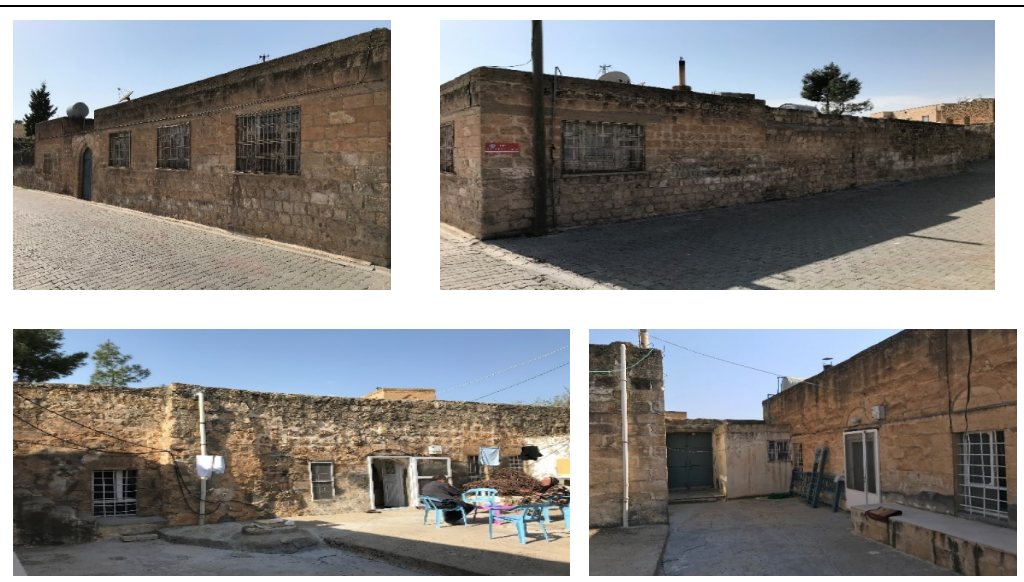

YARD VIEWS

Figure 2. Syriac House No 1 (Kuyumcu, 2019. -Photos were taken by the author-)

Table 2. Syriac house no 1 transparency analysis based on observation survey TRANSPARENCY ANALYSIS BASED ON OBSERVATION AND SURVEY

STRUCTURE ADDRESS: Akçakaya District 111. Street Number: 21

There is a cave in the basement of the structure. It could not be entered into this cave that is not being used. The structure is single-storey and all the living units are located on the ground floor and they are associated

Visual Transwith the yard. The windows of the structure open to the street and the parency yard. When the number sizes of windows in the living units are considered, it has been seen that they are enough in terms of light and ventilation. When the answers given by the users to the $7^{\text {th }}, 10^{\text {th }}$ and $14^{\text {th }}$ questions of the survey are considered, it can be said that the structure is transparent in terms of visual transparency.

Except for the windows for ventilation and light purposes in the structure, it has been observed that the structure was built only with stone Structural masonry walls and no transparent material was used in the construction Transparency of the structure. Thus it has been determined that the building is not transparent (it is opaque) when examined at the constructional dimension.

Perceptual

Although there are windows opening to the street facade, many of them

Transparency open to the yard instead of the street. Also the yard is isolated from the street with the high wall. Also, when considering the users' answers given to the $9^{\text {th }}$ and $13^{\text {th }}$ questions of the survey about the yard and 
window sizes, it can be said that the building is translucent in terms of perceptual transparency.

In terms of planning, the structure consists of two parts as sitting and sleeping. Wet areas and kitchen are located at the yard. The guest is not Cultural isolated from family life. When the users' answers given to $1^{\text {st }}, 2^{\text {nd }}, 4^{\text {th }}, 6^{\text {th }}$, Transparency $8^{\text {th }}$ and $15^{\text {th }}$ questions of the survey are analyzed, it has been understood that the guests coming over use the same spaces with the family members and that family members are not disturbed by this situation. It can be said that the structure is transparent in terms of cultural transparency.

It has been seen that the spaces having windows to the street of the building are generally used as bedrooms and that these windows are covered with iron railings, and that the daily living spaces are associated with the yard. However it has been observed that the yard is isolated from

Psychological the street with the high wall and doors are not opened because of the Transparency uneasiness towards non-Syriac foreigners. In comparison to the Muslims living in the same region, the residents are more closed to communication with the outer world. When considering the users' answers given to the 3rd, 5th, 11th and 12th questions of the survey with these data, it can be said that the structure is opaque in terms of psychological transparency.

\begin{tabular}{llll}
\hline Structure Name: & SURYANI 2 & Structure Type: & MASONRY \\
\cline { 2 - 4 } 2 Structure Order: & ATTACHED & Window protector: & IRON RAILING \\
\hline Facade Number: & 3 FACADES & Garden Walling: & REGIONAL STONES \\
\hline \multicolumn{4}{c}{ FLOOR PLANS } \\
\hline
\end{tabular}




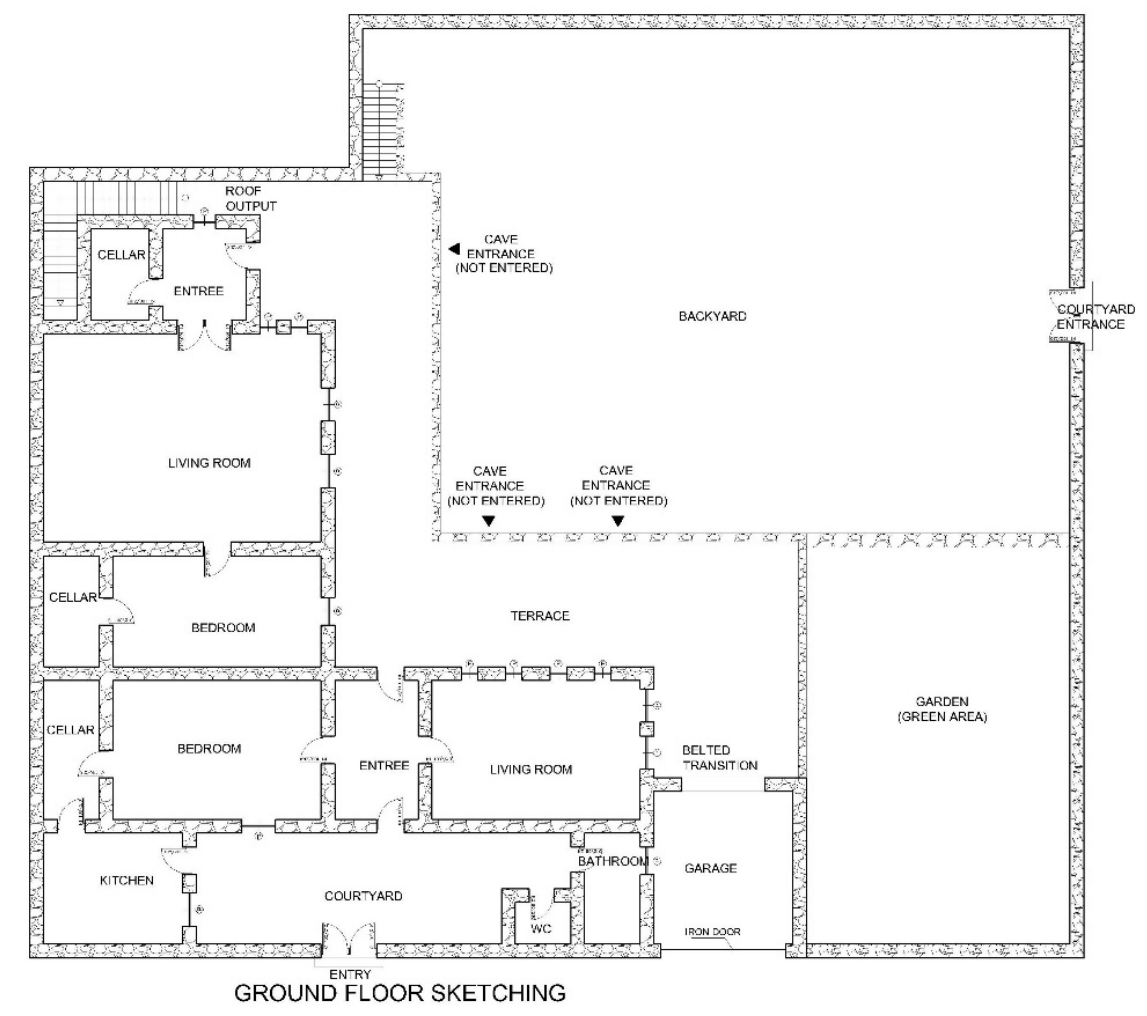

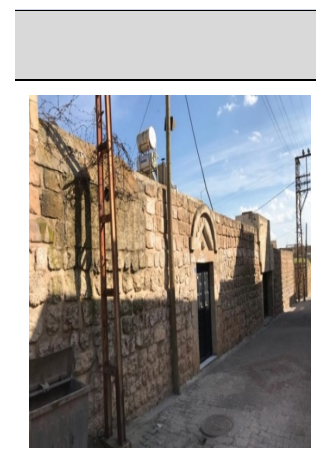

FRONT VIEW

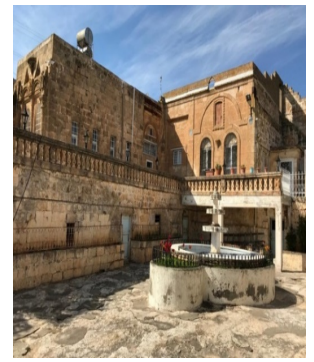

YARD VIEW

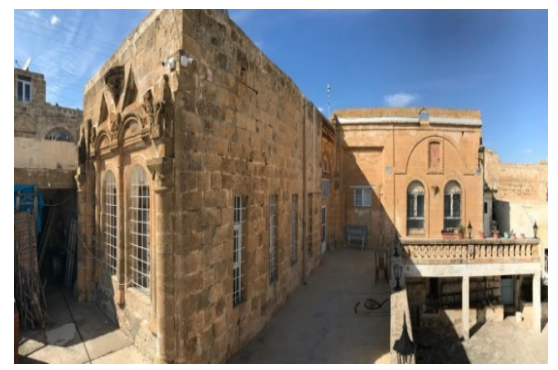

YARD FAÇADE

Figure 3. Syriac House No 2 (Kuyumcu, 2019. -Photos were taken by the author-)

Table 3. Syriac house no 2 transparency analysis based on observation survey TRANSPARENCY ANALYSIS BASED ON OBSERVATION AND SURVEY

\footnotetext{
STRUCTURE ADDRESS: Akçakaya District 126. Street Number: 44
} 
Due to the slope, the structure has two entrances. The lower entrance opens to the yard. The main door of the structure is on the first floor and opens to the street. There are caves used as the yard and storage on the ground floor of the structure and the living units are located on the first Visual Trans- floor. There is no window to the street facade of the structure. All the parency windows open to the terrace facing the yard. It has been seen that the windows' number and the size in the building are enough in terms of ventilation and light. When the answers given by users to the $7^{\text {th }}, 10^{\text {th }}$ and $14^{\text {th }}$ questions are considered, it can be said that the structure is transparent in terms of visual transparency.

It has been seen that except the window structure, no glass or Structural transparent material was used, that regional stone material was used in Transparency the construction of the structure. Thus it has been determined that the building is not transparent (it is opaque) when examined at the constructional dimension.

The windows are enough in terms of number and size. However, it has been observed that all the windows not opening to the street open to the Perceptual yard facade and that the yard is isolated from the street with the high Transparency wall. Also when the answers given by users to the $9^{\text {th }}$ and $13^{\text {th }}$ questions of the survey about the yard entrance and window sizes are considered, it can be said that the structure is opaque in terms of perceptual transparency.

As a result of the examination carried out in the structure and the interviews with the users; it has been understood that Syriacs do not

Cultural

Transparency discriminate between men and women due to their religious beliefs and privacy natures and that the guests are not isolated from family life. Also when the answers given by users to the $1^{\text {st }}, 2^{\text {nd }}, 4^{\text {th }}, 6^{\text {th }}, 8^{\text {th }}$ and $15^{\text {th }}$ questions of the survey are considered, it can be said that the structure is transparent in terms of cultural transparency.

Although Syriacs are not an introverted society and they are hospitable one, it has been seen that they are nervous in terms of security and the doors are not opened to the foreigners and they are closed to the Psychological communication. Also it has been observed that although the structure Transparency windows do not open to the street, they are covered with iron railings. When considering the users' answers given to the $3^{\text {rd }}, 5^{\text {th }}, 11^{\text {th }}$ and $12^{\text {th }}$ questions of the survey with these data, it can be said that the structure is opaque in terms of psychological transparency.

\begin{tabular}{lllll}
\hline & Structure Name: & SURYANI 3 & Structure Type: & MASONRY \\
\cline { 2 - 4 } & Structure Order: & ATTACHED & Window protector: & IRON RAILING \\
\hline
\end{tabular}



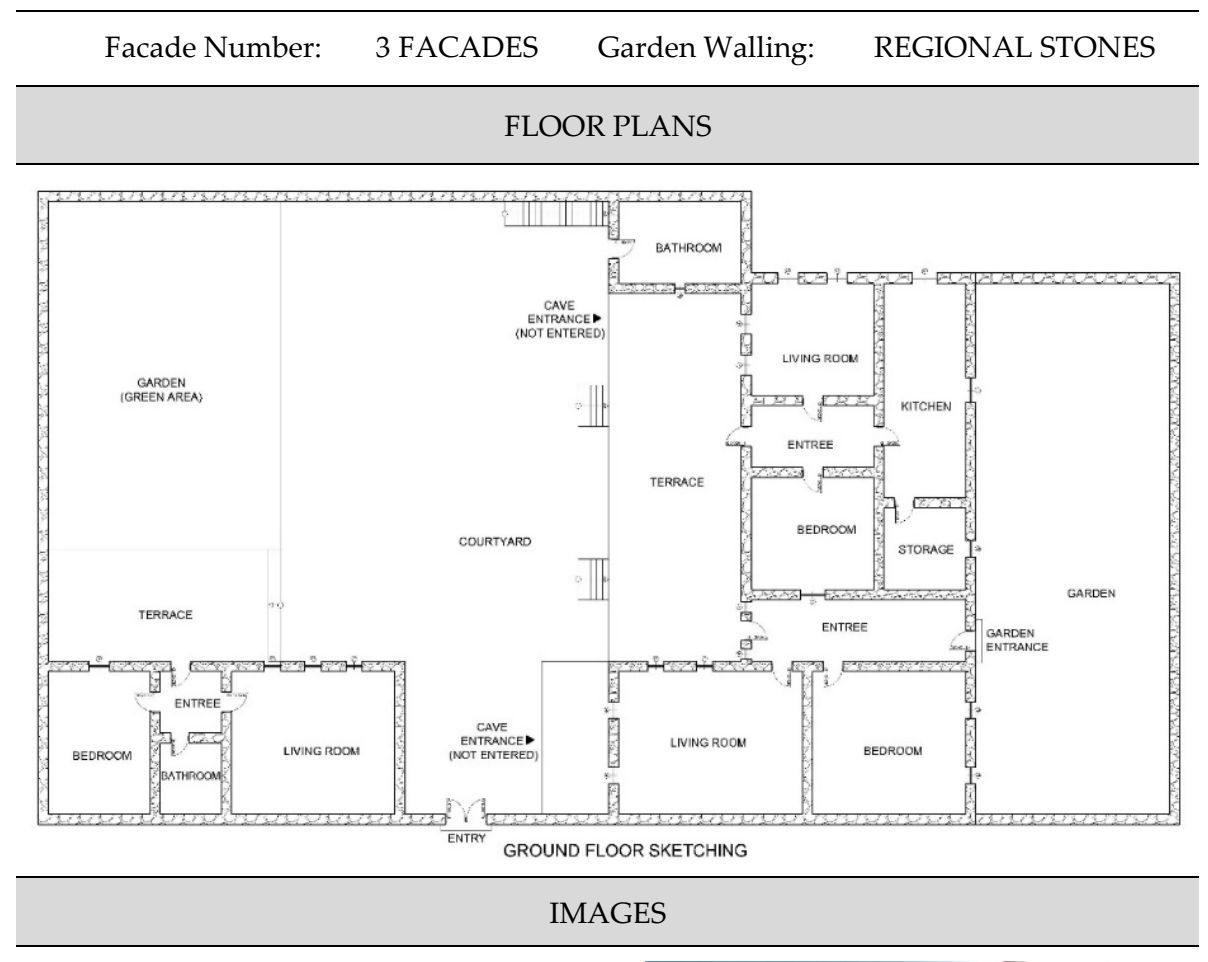

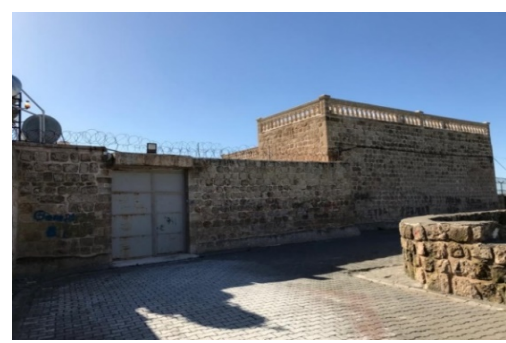

FRONT VIEW

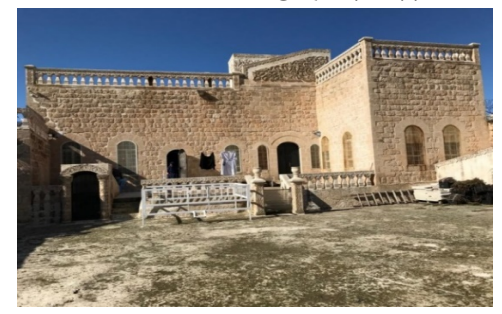

VIEWS FROM THE YARD$$
\text { D }
$$

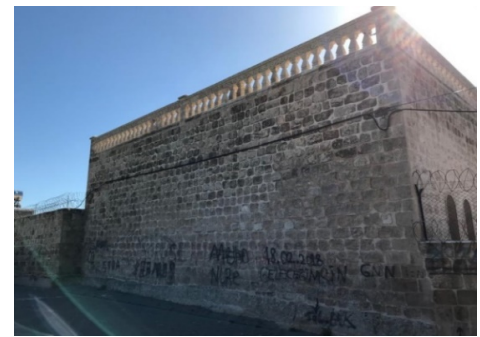

SIDE VIEW

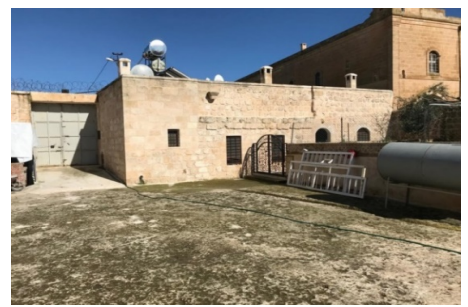

Figure 4. Syriac House No 3 (Kuyumcu, 2019. -Photos were taken by the author-) Table 4. Syriac house no 3 transparency analysis based on observation survey TRANSPARENCY ANALYSIS BASED ON OBSERVATION AND SURVEY 
STRUCTURE ADDRESS: Akçakaya District 129. Street Number: 4

The cave (could not be entered) is located at the basement floor, living units are located on the first floor of the structure. When the number

Visual and sizes of the windows of the living units are considered, it has been

Transparency observed that the spaces are enough in terms of light and air needs. When the answers given by users to the $7^{\text {th }}, 10^{\text {th }}$, and $14^{\text {th }}$ questions of the survey are considered, it can be said that the structure is transparent in terms of visual transparency.

When the structure is analyzed in terms of construction materials used in the construction; mostly solid materials have been seen in the walls Structural and floors. It has been observed that the windows in the spaces are Transparency only used for sunlight and ventilation purposes. Thus, it has been determined that the structure is not transparent (it is opaque) when examined at the constructional dimension.

It has been observed that windows open to the yard, that there is no window on the street facade, that the yard is isolated from the street

Perceptual with the high wall.

Transparency

Also when the answers given by users to the 9th and 13th questions of the survey about the yard entrance and window sizes are considered, it can be said that the structure is opaque in terms of perceptual transparency.

It has been observed that there are many spaces with the aim of meeting the needs of the large family however; no separate space is used for the guests. Based on the religious beliefs and privacy

Cultural conceptions, it has been understood that there is no need to separate

Transparency spaces of men and women and that the guest is not isolated from family life. When the answers given by users to the $1^{\text {st }}, 2^{\text {nd }}, 4^{\text {th }}, 6^{\text {th }}, 8^{\text {th }}$ and $15^{\text {th }}$ questions of the survey are analyzed, it can be said that the structure is transparent in terms of cultural transparency.

It has been seen that the structure does not have a window opening to the street, that garden and yard are isolated from the street with high walls and despite this, windows are covered with iron railings. It has

Psychological Transparency been observed that in case Syriac is not spoken, the door is not opened to foreigners. It has been thought that since Syriacs are a minority in this region, they need to take such measures in terms of security. When considering the users' answers given to the $3^{\text {rd }}, 5^{\text {th }}, 11^{\text {th }}$ and $12^{\text {th }}$ questions of the survey with these data, it can be said that the structure is opaque in terms of psychological transparency.

\begin{tabular}{lllll}
\hline 4 & Structure Name: & SURYANI 4 & Structure Type: & MASONRY \\
\cline { 2 - 4 } & Structure Order: & ATTACHED & Window protector: & IRON RAILING \\
\hline
\end{tabular}




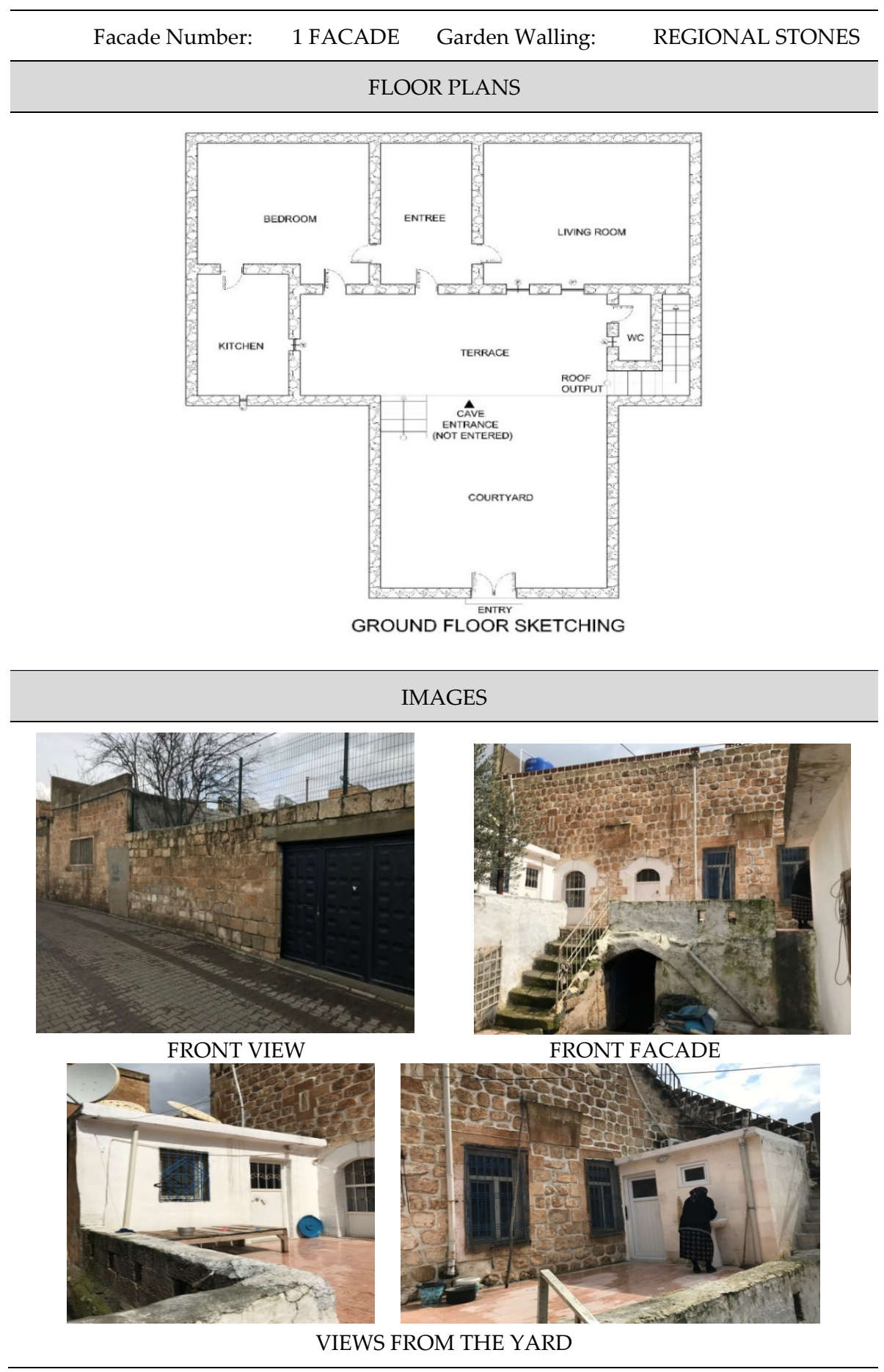


Figure 5. Syriac House No 4 (Kuyumcu, 2019. -Photos were taken by the author-)

Table 5. Syriac house no 4 transparency analysis based on observation survey TRANSPARENCY ANALYSIS BASED ON OBSERVATION AND SURVEY

\author{
STRUCTURE ADDRESS: Işıklar District Şen Street Number: 11
}

The cave (could not be entered) is located on the basement floor, living
units are located on the first floor of the structure. When the number and
Vizes of the windows of the living units are considered, it has been
parency
observed that the spaces are not enough in terms of light and air needs.
When the answers given by users to the $7^{\text {th }}, 10^{\text {th }}$, and $14^{\text {th }}$ questions of the
survey are considered, it can be said that the structure is transparent in
terms of visual transparency.

When the structure is analyzed in terms of construction materials used in the construction; mostly solid materials have been seen in the walls and floors. It has been observed that the windows in the spaces are only Structural used for sunlight and ventilation purposes. Thus, it has been determined Transparency that the structure is not transparent when examined at the constructional dimension. No transparent material was used in the construction of the structure. Thus it has been determined that the building is not transparent (it is opaque) when examined at the constructional dimension.

\begin{tabular}{ll}
\hline Perceptual & $\begin{array}{l}\text { No windows are opened to the street facade of the structure. Since the } \\
\text { Transparency is isolated from the street with the high wall, it has given a } \\
\text { perceptually opaque impression when it is viewed from the street. } \\
\text { Also when the answers given by users to the } 9^{\text {th }} \text { and } 13^{\text {th }} \text { questions of the } \\
\text { survey about the yard entrance and window sizes are considered, it can } \\
\text { be said that the structure is opaque in terms of perceptual transparency. }\end{array}$ \\
& $\begin{array}{l}\text { Syriacs do not have an introverted lifestyle. In terms of planning, the } \\
\text { structure consists of two parts as sitting and sleeping. It has been } \\
\text { observed that the guests coming over use the same spaces with family } \\
\text { members and they are not isolated from the family life and that there is } \\
\text { Transparency } \\
\text { no need to separate the spaces of men-women } \\
\text { Also when the users' answers given to } 1^{\text {st }}, 2^{\text {nd }}, 4^{\text {th }}, 6^{\text {th }}, 8^{\text {th }} \text { and } 15^{\text {th }} \\
\text { questions of the survey are analyzed, it can be said that the structure is } \\
\text { transparent in terms of cultural transparency. }\end{array}$ \\
\hline $\begin{array}{l}\text { Although they have an extrovert nature culturally, the house is isolated } \\
\text { from the street completely. Although the windows are opened to the } \\
\text { Transparency }\end{array}$ \\
$\begin{array}{l}\text { yard, they are covered with iron railings. It has been observed that the } \\
\text { doors are not opened (if they are opened, anxiety is experienced) to the } \\
\text { foreigners who do not know Syriac due to security reasons. } \\
\text { When considering the users 'answers given to the } 3 \text { rd, 5th, } 11 \text { th and } 12 \text { th } \\
\text { questions of the survey with these data, it can be said that the structure } \\
\text { is opaque in terms of psychological transparency. }\end{array}$ \\
\hline
\end{tabular}




\begin{tabular}{lllll}
\hline & Structure Name: & SURYANI 5 & Structure Type: & MASONRY \\
\cline { 2 - 4 } & Structure Order: & ATTACHED & Window protector: & IRON RAILING \\
\cline { 2 - 4 } & Facade Number: & 2 FACADES & Garden Walling: & REGIONAL STONES \\
\hline \multicolumn{5}{c}{ FLOOR PLANS } \\
\hline
\end{tabular}
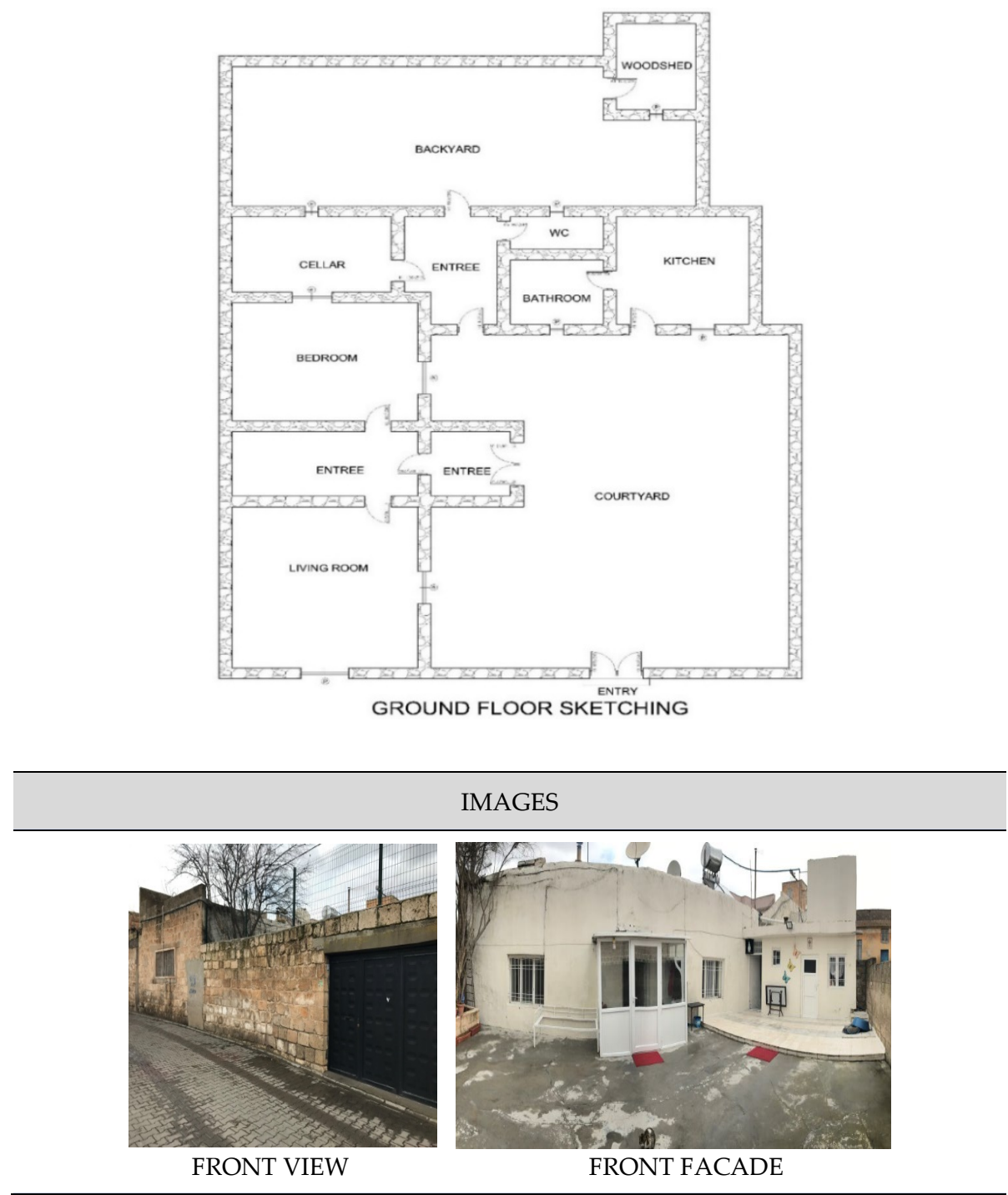

Figure 6. Syriac House No 5 (Kuyumcu, 2019. -Photos were taken by the author-) 
Table 6. Syriac house no 5 transparency analysis based on observation survey TRANSPARENCY ANALYSIS BASED ON OBSERVATION AND SURVEY

STRUCTURE ADDRESS: Işılar District Şen Street Number: 17

The structure has one floor and two yards. The entrance yard is isolated from the street with the high wall. It has windows opening both to the

Visual Transparency

Transparency

Perceptual

Transparency

Transparency

Psychological

Transparency street and the yard facade. It has been observed that it is enough in terms of ventilation and receiving light when the windows' number and size in living units are considered. When also the answers given by users to the $7^{\text {th }}, 10^{\text {th }}$, and $14^{\text {th }}$ questions of the survey are considered, it can be said that the structure is transparent in terms of visual transparency.

Mostly, solid materials have been used in the construction of the structure. In the construction of window, glass material has been used and no transparent material has been used in the construction of the structure. Windows in the spaces have only been used with the aim of receiving sunlight and ventilating the space. Thus, it has been determined that the structure is not transparent when examined at the constructional dimension.

Since the yard is isolated from the street with the high wall, it has given a perceptually opaque impression when it is viewed from the street. However, the structure has window to the street facade and has not been isolated completely. Also when the answers given by users to the $9^{\text {th }}$ and $13^{\text {th }}$ questions of the survey are considered, it can be said that the structure is translucent in terms of perceptual transparency.

It has been observed that in terms of planning, the structure consists of two parts as sitting and sleeping and that there is no need to separate the spaces of men-women. The guests coming over use the same spaces with family members and they are not isolated from the family life. Also when the users' answers given to $1^{\text {st }}, 2^{\text {nd }}, 4^{\text {th }}, 6^{\text {th }}, 8^{\text {th }}$ and $15^{\text {th }}$ questions of the survey are analyzed, it can be said that the structure is transparent in terms of cultural transparency.

It has been seen that the window opening to the street is higher than it is supposed to be and that it does not provide street interaction with the structure and the window is covered with the iron railings. The yard is isolated from the street with the high wall. It has been observed that the doors are not opened (if they are opened, anxiety is experienced) to the foreigners who do not know Syriac due to security reasons.

When considering the users 'answers given to the 3rd, 5th, 11th and 12th questions of the survey, it can be said that the structure is opaque in terms of psychological transparency. 


\section{Discussion and Conclusion}

Examining the Syriac Houses in Midyat, to what extent and how transparency affects house forming has been determined in terms of privacy conceptions. As a result of the findings, it has been observed that societies' socio-cultural structure, religious beliefs and lifestyles shape the privacy phenomenon of that society and that these privacy conceptions are influential in shaping the architectural structure in terms of privacy. People's lifestyle and privacy conception has influenced the house both in the interior arrangement and its connection with the outer world that is with the transparency level on the facades.

Surveys have been carried out with those living in traditional Syriac houses in the Midyat central districts and house plans have been drawn. Transparency analysis of the houses examined has been evaluated as opaque, translucent and transparent and the chart below has been created. By marking the opaque, translucent and transparent state of the houses, a legend has been created in the chart. In the legend; " $\mathbf{O}$ " stands for opacity," $\mathbf{0}$ " translucency, " $\circ$ " transparency (Table 7).

Table 7. Syriac houses transparency analysis based on observation

\begin{tabular}{lllllllllllllllllllllll}
\hline 11 & \multicolumn{11}{c}{ SYRIAC HOUSES } \\
\hline $\begin{array}{l}\text { Home } \\
\text { Number: }\end{array}$ & 1 & 2 & 3 & 4 & 5 & 6 & 7 & 8 & 9 & 1 & 1 & 1 & 1 & 1 & 1 & 1 & 1 & 1 & 1 & 2 \\
\hline $\begin{array}{l}\text { Visual } \\
\begin{array}{l}\text { Transpar- } \\
\text { ency }\end{array}\end{array}$ & $\circ$ & $\circ$ & $\circ$ & $\circ$ & $\circ$ & $\circ$ & $\circ$ & $\circ$ & $\circ$ & $\circ$ & $\circ$ & $\circ$ & $\circ$ & $\mathbf{0}$ & $\circ$ & $\circ$ & 0 & $\circ$ & $\mathbf{0}$ & $\circ$ \\
\hline
\end{tabular}

Structural-

Trans.

Perceptual

Trans.

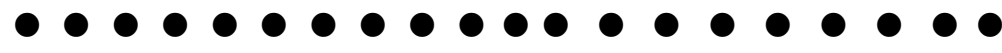

Cultural

Trans.

Psycholog-

ical Trans.

opaque $\mathbf{O}$ translucent $\circ$ transparent

When the survey and space organizations carried out with Syriac families are examined, it has been seen that Syriacs have a transparent lifestyle in 
terms of culture, and that these features reflect on space organizations and structure facades but due to security needs, windows are not opened on the street facades of houses and on the ground floor. Also it has been seen that the windows that are opened, are covered with iron railings. As a result of the survey analysis and evaluations; it has been understood that Syriacs are not bothered with the transparency concept and they are a transparent society in terms of culturally and visually. However, it has been observed that in terms of perceptual, structural and psychological transparency, this transparency is not reflected much in their houses.

\section{Kaynakça/References}

Altman, I. \& Low, S. (1992). Place attachment. New York: Plenum Press.

Asımgil, B. (2006). Geçmişten günümüze şeffaf mimari uygulamalarda tarihsel yorumlar. Afyon Kocatepe Üniversitesi Fen Bilimleri Dergisi, 6(1), 67-80.

Aytıs, S. \& Göker, M. (2010). Mimari yapılarda saydamlık ve mekan tasarımında ışı kontrolü. Tasarm Kuram Dergisi, 9(10), 82-92.

Colombijn, F. \& Erdentuğ, A. (2002). Urban ethnic encounters: The spatial consequences. (1st Edition) London: Routledge.

Çelik Z. (2010). Kentler: Anadolu'nun dönüşümü, Türkiye'nin geleceği. İdealkent Dergisi, 1, 154-159.

Erman T. (2010). Kent çeperindeki bir 'devrimci' mahalle: 1970'lerden 2000'lere mahallenin değişen anlamı ve mahalle üzerinde yaşanan çatışmalar, çekişmeler. Idealkent Dergisi, 2, 170-195.

Fabian, A. K., Kaminoff, R. \& Proshansky, H. M., (1983). Place identity: Physical world socialization of the self. Journal of Environmental Psychology, 3, 57-83.

Google Earth, (2020, Şubat 20). Map of Midyat and Syriac Houses Examined. Accessed February 20, 2020 from https://www.earth.google.com/web/

İleriye, M. U. (2007). Mimarlıkta saydamlık düşüncesi. (Yayımlanmamış yüksek lisans tezi). Yıldız Teknik Üniversitesi, İstanbul.

Karagülle, C. (2009). Yerel verilerin konut tasarım sürecinde değerlendirilmesi: Mardin örneği. (Yayımlanmamış doktora tezi). İstanbul Teknik Üniversitesi, İstanbul.

Keith, M. \& Pile, S. (1993). Introduction part 1 and 2: the politics of place. Keith M. \& Pile S. (Ed.), Place and the politics of identity (s.1-40). London: Routledge

Keskin, K. \& Zorlu, T. (2017). Kültür-konut etkileşiminde mahremiyet olgusu: Geleneksel Urfa-Akçaabat/Ortamahalle evleri üzerinden karşılaştırmalı bir analiz. Online Journal of Art and Design, 72-89.

Kuyumcu, M. A. (2019). Farkl etnik gruplara ait konut mimarisinde şeffaflı kavrammin mahremiyet olgusu açısından incelenmesi: Geleneksel Midyat evleri örneği. (Yayımlanmamış yüksek lisans tezi). Dicle Üniversitesi, Diyarbakır.

Lovell, N., (1998). Locality and belonging. (1st Edition) London: Routledge. 
Patterson, M. E., Roggenbuck, J. W., Watson, A. E. \& Williams, D. R. (1992). Beyond the commodity metaphor: Examining emotional and symbolic attachment to place. Leisure Sciences 14(1), 29-46.

Rifaioğlu M. N. \& Uçar M. (2011). Yerel kimliğin mekânsal temsili ve Québec kentinde korunmasi. İdealkent Dergisi, 3, 62-81.

Rivlin, L.G., (1987). The neighborhood, personal identity, and group affiliations, Altman, I. and Wandersman, A. (Ed.), Neighborhood and community environments (s. 1-34). Boston: Springer

Şengül, B. A. (2017). Mardin'de kültürlerarası yaşam: Konut mimarisi bağlamında bir değerlendirme. Hacettepe Üniversitesi Türkiyat Araştırmalan Dergisi, 7-60.

Türk Dil Kurumu, (2019, Şubat 18). Accessed February 18, 2019 from https://www.tdk.gov.tr 